\title{
Hypothalamo-pituitary-adrenal function in intrinsic non-atopic asthma
}

\author{
J. V. C O L L I N S, D. B E L L A M Y, M. G. B R I T T O N, \\ J . T O W N S N D, a n d D. J. B R O W N \\ St. Bartholomew's Hospital, London EC1A 7BE
}

\begin{abstract}
Collins, J. V., Bellamy, D., Britton, M. G., Townsend, J., and Brown, D. J. (1975). Thorax, 30, 578-581. Hypothalamo-pituitary-adrenal function in intrinsic non-atopic asthma. Sixteen patients with intrinsic non-atopic asthma with persistent wheezing who had never been treated with corticosteroids showed normal adrenocortical responses to prolonged stimulation with Tetracosactin Depot. In a subgroup of six patients the hypothalamo-pituitary-adrenal (HPA) response to a standard insulin stress test was normal. It is concluded that impaired responsiveness of the HPA axis is unlikely to be a common factor in initiating or maintaining airways obstruction in patients with intrinsic asthma.
\end{abstract}

The relationship of adrenocortical function and bronchial asthma has long been the subject of controversy (Editorial, 1965). Enhancement of bronchial hypersensitivity in guinea-pigs following adrenalectomy was reported by Képinov (1922), and Rackemann (1945) found low urinary 17-keto steroid excretion in one patient with asthma. Bronchial asthma may rarely be a presenting feature in Addison's disease (Green and Lim, 1971). Earlier reports from different authors of studies of adrenocortical function in asthma showed discrepancies which may have resulted from variations in the methods and accuracy of the hormonal assay employed. An association between intrinsic asthma and subnormal adrenocortical function has been suggested (Robson and Kilborn, 1965). The present study examines hypothalamo-pituitary-adrenal (HPA) function in patients with intrinsic nonatopic asthma.

\section{PATIENTS AND METHODS}

Twenty patients with bronchial asthma were studied after admission to hospital for a trial of corticosteroids because of poor control of symptoms. Each patient had suffered persistent and, in some cases, continuous wheezing since the onset of asthma but had never been treated with adrenal stimulation or corticosteroids. At the time of the studies each patient had clinical and spirometric evidence of airways obstruction but none had significantly abnormal blood ga果 tensions. All patients gave informed consent t $\Theta$ the studies.

In all patients the blood eosinophil count waฐ in excess of $500 / \mathrm{mm}^{3}$ and the sputum eosinophi count was $40 \%$ or more. Sixteen patients were. classed as intrinsic non-atopic asthmatics becauset they had no history of hypersensitivity an\& showed no immediate or delayed reactions to skifr prick tests with a range of 23 common allergens (see Appendix). The four remaining patients who were classed as extrinsic atopic subjects showe@ significant positive immediate reactions to two or more common allergens and reported sympo toms related to exposure to house dust, pollens of domestic pets.

All studies were begun between 8.00 anf 10.00 am with the patient semirecumbent after an overnight fast. Blood samples for estimatiop of plasma cortisol levels were obtained through an indwelling venous cannula inserted into $a$ forearm vein one hour before the start of the study. Blood samples were centrifuged im mediately, and plasma was stored at $4^{\circ} \mathrm{C}$ untif cortisol levels were estimated, using a modifica tion of the method of Mattingley (1962). Eact sample was analysed in duplicate.

In six of the intrinsic non-atopic patients $\underset{\mathbb{Q}}{\mathbb{Q}}$ standard insulin stress test was performed on the first day using a single intravenous injection of 
soluble insulin, $0 \cdot 15$ unit per $\mathrm{kg}$ body weight. On the second day in these patients and in all the remaining patients a prolonged Synacthen (Tetracosactin) stimulation test was performed with an intramuscular injection of $1 \mathrm{mg}$ Synacthen Depot.

\section{RESULTS}

Statistical analyses of clinical and laboratory details for the two groups of patients are shown in Table $I$ and for the responses to Synacthen stimulation tests and insulin stress tests are shown in Tables II and III.

Using $t$-statistics for unequal variances the results of the Synacthen stimulation tests in the 16 patients with intrinsic asthma were compared with values obtained in 107 normal subjects (Ciba), and the results of the insulin stress tests were compared with values for 12 normal subjects reported by Landon, Wynn, and James (1963). In every patient there was a brisk and sustained rise in plasma cortisol level in response to Synacthen with an increment above the resting level of at least $200 \mathrm{nmol} / 1$ at 30 minutes after injection. The mean and SD of the increment for the patients with intrinsic asthma $(460 \pm 174 \mathrm{nmol} / \mathrm{l})$ were not significantly different from those for normal subjects $(457 \pm 223 \mathrm{nmol} / 1)$. The plasma cortisol levels for the intrinsic asthmatics were significantly higher $(P<0.05)$ than for normal subjects at each interval to five hours after injection of Synacthen. Moreover in seven of these patients in whom levels were measured at 8 and 24 hours after injection there was evidence of a sustained response to stimulation (see Table II). Similar

T A B L E I

CLINICAL DETAILS OF PATIENTS WITH ASTHMA

\begin{tabular}{|c|c|c|c|c|}
\hline & $\begin{array}{l}\text { Age } \\
(y r)\end{array}$ & $\begin{array}{c}\text { Duration of } \\
\text { Asthma } \\
(y r)\end{array}$ & $\underset{\substack{\text { Sputum } \\
\text { Eosinophilia }}}{\stackrel{0}{\%}}$ & 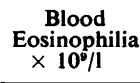 \\
\hline $\begin{array}{l}16 \text { intrinsic patients } \\
\text { Mean } \\
\text { SD } \\
\text { SEM }\end{array}$ & $\begin{array}{r}51 \cdot 3 \\
11 \cdot 5 \\
2 \cdot 9\end{array}$ & $\begin{array}{l}9 \cdot 6 \\
7 \cdot 6 \\
1 \cdot 9\end{array}$ & $\begin{array}{r}63 \cdot 1 \\
11 \cdot 8 \\
3 \cdot 0\end{array}$ & $\begin{array}{l}0 \cdot 790 \\
0 \cdot 256 \\
0 \cdot 065\end{array}$ \\
\hline $\begin{array}{l}4 \text { extrinsic patients } \\
\text { Mean } \\
\text { SD } \\
\text { SEM }\end{array}$ & $\begin{array}{r}28 \cdot 8 \\
14 \cdot 5 \\
7 \cdot 3\end{array}$ & $\begin{array}{r}18.5 \\
18.7 \\
9.4\end{array}$ & $\begin{array}{r}56 \cdot 3 \\
8 \cdot 5 \\
4 \cdot 3\end{array}$ & $\begin{array}{l}0.770 \\
0.146 \\
0.074\end{array}$ \\
\hline
\end{tabular}

T A B L E I I

PLASMA 11-HYDROXYCORTICOSTEROID (11-OHCS) LEVELS AFTER INJECTION OF $1 \mathrm{mg}$ SYNACTHEN DEPOT

\begin{tabular}{|c|c|c|c|c|c|c|c|c|c|}
\hline \multirow[b]{2}{*}{ Hours } & \multicolumn{9}{|c|}{ Plasma 11-OCHS (nmol/1) after Synacthen } \\
\hline & $\mathbf{0}$ & $\frac{1}{2}$ & 1 & 2 & 3 & 4 & 5 & $8^{1}$ & $24^{1}$ \\
\hline $\begin{array}{l}16 \text { intrinsic patients } \\
\text { Mean } \\
\text { SD } \\
\text { SEM }\end{array}$ & $\begin{array}{r}377 \\
121 \\
30\end{array}$ & $\begin{array}{r}840 \\
184 \\
47\end{array}$ & $\begin{array}{r}1085 \\
322 \\
80\end{array}$ & $\begin{array}{r}1209 \\
220 \\
55\end{array}$ & $\begin{array}{r}1336 \\
245 \\
61\end{array}$ & $\begin{array}{r}1435 \\
215 \\
55\end{array}$ & $\begin{array}{r}1512 \\
245 \\
61\end{array}$ & $\begin{array}{r}1526 \\
253 \\
66\end{array}$ & $\begin{array}{r}1449 \\
160 \\
41\end{array}$ \\
\hline $\begin{array}{l}4 \text { extrinsic patients } \\
\text { Mean } \\
\text { SD } \\
\text { SEM }\end{array}$ & $\begin{array}{r}408 \\
138 \\
69\end{array}$ & $\begin{array}{r}848 \\
132 \\
66\end{array}$ & $\begin{array}{r}1102 \\
149 \\
74\end{array}$ & $\begin{array}{r}1226 \\
83 \\
41\end{array}$ & $\begin{array}{r}1358 \\
113 \\
58\end{array}$ & $\begin{array}{r}1399 \\
185 \\
94\end{array}$ & $\begin{array}{r}1460 \\
251 \\
127\end{array}$ & $\begin{array}{r}1736 \\
482 \\
242\end{array}$ & $\begin{array}{r}1424 \\
413 \\
207\end{array}$ \\
\hline
\end{tabular}

Number of intrinsic subjects $=7$.

T A B L E I I I

SIX PATIENTS WITH INTRINSIC ASTHMA: PLASMA 11-OCHS LEVELS FOLLOWING IV INJECTION OF SOLUBLE INSULIN $0 \cdot 15 \mu \mathrm{g} / \mathrm{kg}$ BODY WEIGHT

\begin{tabular}{|c|c|c|c|c|c|c|c|c|}
\hline & \multirow{3}{*}{$\begin{array}{c}\text { Lowest Blood } \\
\text { Sugar } \\
(\mathrm{mmol} / \mathrm{l})\end{array}$} & \multicolumn{6}{|c|}{ Plasma 11-OCHS Levels (nmol/1) } & \multirow{3}{*}{$\begin{array}{l}\text { Maximum } \\
\text { Increment }\end{array}$} \\
\hline & & \multicolumn{6}{|c|}{ Minutes after iv insulin } & \\
\hline & & 0 & 30 & 45 & 60 & 90 & 120 & \\
\hline $\begin{array}{l}\text { Mean } \\
\text { SD } \\
\text { SEM }\end{array}$ & $\begin{array}{l}1 \cdot 43 \\
0.31 \\
0.12\end{array}$ & $\begin{array}{r}388 \\
157 \\
63\end{array}$ & $\begin{array}{r}477 \\
129 \\
52\end{array}$ & $\begin{array}{r}743 \\
99 \\
41\end{array}$ & $\begin{array}{r}804 \\
96 \\
39\end{array}$ & $\begin{array}{r}868 \\
171 \\
69\end{array}$ & $\begin{array}{r}865 \\
240 \\
96\end{array}$ & $\begin{array}{r}587 \\
196 \\
80\end{array}$ \\
\hline
\end{tabular}


results were obtained for the four patients with extrinsic asthma but the small numbers made statistical comparisons less valid. The insulin stress test in six patients with intrinsic asthma showed normal responses. In every patient the blood sugar level fell below $2 \cdot 22 \mathrm{mmol} / 1$, the maximum plasma cortisol exceeded $550 \mathrm{nmol} / \mathrm{l}$, and the increment above the basal level was at least $275 \mathrm{nmol} / 1$. The mean and SD for the maximum increment was $587 \pm 196 \mathrm{nmol} / 1$ in patients with asthma compared with $353 \pm 102 \mathrm{nmol} / 1$ in normal subjects.

\section{DISCUSSION}

In the present study adrenocortical function was normal in patients with extrinsic asthma, and this agrees with previous reports (Blumenthal et al., 1966; Weller et al., 1968). Weller et al. (1968) found that cortisol production rates were normal in patients with extrinsic asthma in the ambulant state but were diminished at rest. The adrenal response to ACTH infusions was normal in their patients but the response to pyrogen stimulation tests was slightly but significantly impaired. Robson and Kilborn (1965) studied patients with continuous asthma and inferred from the experience of Ogilvie (1962) that their asthma was intrinsic in type. In these patients, cortisol production rates were normal at rest but the response to ACTH stimulation was impaired in $68 \%$. There was an inverse relationship between the duration of symptoms and the response to ACTH. Both Weller et al. (1968) and Robson and Kilborn (1965) discussed the possibility that adrenocortical insufficiency may precede or result from the effects of asthma. The association of asthma with Addison's disease appears to be uncommon in the absence of previous steroid treatment (Carryer, Sherrick, and Gastineau, 1960; Green and Lim, 1971). Similarly, in patients admitted to hospital with status asthmaticus signs of hypoadrenalism are uncommon even in patients who have received previous treatment with corticosteroids (Cayton and Howard, 1973). Adrenal atrophy has rarely been recorded in patients dying of asthma in the absence of previous steroid treatment (Speizer et al., 1968; Green and Lim, 1971; Fraser et al., 1971). Airways obstruction of itself does not seem to be associated with impaired adrenocortical function, for in patients with chronic bronchitis and severe fixed airways obstruction Weston and Kind (1969) found normal adrenocortical responses to ACTH.

The present study has failed to show any rela- tionship between intrinsic non-atopic asthma and impairment of HPA responses. There was no ev dence that increasing age or duration of asthme affected the adrenocortical response to stimula $\mathbb{B}$ tion by stress or Synacthen. The plasma cortisog levels recorded in our patients were higher than those previously reported for normal subjects using the same assay methods (Ciba; Lando et al., 1963). This suggests that in patients sub? jected to the stimulus of persistent asthma adrena差 mass may be increased, as has been reported in patients dying with cardiovascular diseases and malignant neoplasms (Studzinski, Hay, and Symington, 1963). Examination of reports of necropsy findings in patients dying of asthma has failed to reveal details of adrenal size in most patients (Houston, Nevasquez, and Trounce, 195 Speizer et al., 1968).

It seems unlikely that impaired responsivenes of the HPA axis is an important or common factor in precipitating or maintaining airway oby struction in patients with asthma except where previous corticosteroid treatment has resulted io suppression. Clinical experience of the efficacy of supraphysiological plasma levels of cortisol of synthetic substitutes in the treatment of asthm may have resulted in an over-emphasis of the role which impaired HPA responses play in asthma.

\section{APPENDIX}

All patients were tested for hypersensitivity by standard prick test with the following solution produced by Bencard Ltd:

Control, house dust, Dermatophagoide pteronyssinus, grass pollen, shrub pollens, treg pollens, cat fur, dog hair, horse hair, feathers mixed, pigeon feathers, budgerigar feather $\$$ alternaria, A spergillus fumigatus, Cladosporium dry rot, Sporobolomyces, yeast, Candida, alb cans, milk, eggs, wheat, fish, nuts.

\section{REFERENCES}

Blumenthal, M. N., McLean, J. A., Mathews, K. ?2 and Sheldon, J. M. (1966). Adrenal-pituitary function in bronchial asthma. Archives of Internal Medicine, 117, 23.

Carryer, H. M., Sherrick, D. W., and Gastineau் C. F. (1960). Occurrence of allergic disease if patients with adrenal cortical hypofunction Journal of the American Medical Association 172, 1356.

Cayton, R. M. and Howard, P. (1973). Plasma cort sol and the use of hydrocortisone in the treat ment of status asthmaticus. Thorax, 28, 567. 
Ciba. Synacthen, Table 2, p. 10. Ciba, Horsham, Surrey.

Editorial (1965). Adrenal function and asthma. Lancet, 1, 853.

Fraser, P. M., Speizer, F. E., Waters, S. D. M., Doll R., and Mann, N. M. (1971). The circumstances preceding death from asthma in young people in 1968 to 1969. British Journal of Diseases of the Chest, 65, 71.

Green, M. and Lim, K. H. (1971). Bronchial asthma with Addison's disease. Lancet, 1, 1159.

Houston, J. C., Navasquez, S. De., and Trounce, J. R. (1953). A clinical and pathological study of fatal cases of status asthmaticus. Thorax, 8, 207.

Képinov, L. (1922). Simenarities et anaphylaxie. Comptes Rendus des Séances de la Société de Biologie, 87, 327.

Landon, J., Wynn, V., and James, V. H. T. (1963). The adrenocortical response to insulin-induced hypoglycaemia. Journal of Endocrinology, 27, 283.

Mattingley, D. (1962). A simple fluorimetric method for the estimation of free 11-hydroxycorticoids in human plasma. Journal of Clinical Pathology, 15, 374.

Ogilvie, A. G. (1962). Asthma: A study in prognosis of 1000 patients. Thorax, 17, 183.
Rackemann, F. M. (1945). Depletion in asthma. Journal of Allergy, 16, 136.

Robson, A. O., and Kilborn, J. R. (1965). Studies of adrenocortical function in continuous asthma. Thorax, 20, 93.

Speizer, F. E., Doll, R., Heaf, P., and Strang, L. B. (1968). Investigation into use of drugs preceding death from asthma. British Medical Journal, 1, 339 .

Studzinski, G. P., Hay, D. C. F., and Symington, T. (1963). Observations on the weight of the human adrenal gland and the effect of preparations of corticotropin of different purity on the weight and morphology of the human adrenal gland. Journal of Clinical Endocrinology, 23, 248.

Weller, H. H., Straeten, M. van der, Vermeulen, A., and Orie, N. G. M. (1968). Hormonal pattern in bronchial asthma. Scandinavian Journal of Respiratory Diseases, 49, 163.

Weston, N. and Kind, P. (1969). Plasma cortisol and response to corticotrophin in airways obstruction. British Journal of Diseases of the Chest, 63, 48.

Requests for reprints to: Dr. J. V. Collins, The Lung Function Laboratory, St. Bartholomew's Hospital, London EC1. 